\title{
PENGARUH KUALITAS PELAYANAN DAN HARGA TERHADAP LOYALITAS PELANGGAN DENGAN KEPUASAN PELANGGAN SEBAGAI VARIABEL INTERVENING PADA PT. SUNGGONG LOGISTICS
}

\author{
Tri Martiani LN, Subagiyo* \\ *Dosen Tetap Program S1 Jurusan Manajemen Fakultas Ekonomi Universitas Satya Negara Indonesia \\ bagyolink@,cbn.net.id@gmail.com.
}

\begin{abstract}
In the high competition of the forwarder industry, having a big names and a lot of fleets is not enough. Standard customer requirements are always increase. Customer satisfaction is very important for any service company, but some studies show that satisfaction of customers is not enough. Because there is no guarantee that satisfied customers will become loyal customers. Therefore, it is important for service companies to provide the quality of service which expected by the costumers with the competitive price. This research is conducted to analyze the correlation between service quality and price to customer loyalty with customer satisfaction as the intervening variable. This research uses multiple linear regression analysis and using two structural models with SPSS program. The population used is consumer of PT. Sunggong Logistics. While the sample used counted 100 people with sample selection technique using probability sampling.

The results indicates that there is a positive and significant influence between service quality to customer satisfaction. There is a positive and significant influence between price and customer satisfaction.There is a positive and significant influence between service quality and price with customer satisfaction. There is no direct positive and significant influence between the quality of Service to customer loyalty. There is a positive and significant direct effect of price on customer loyalty. There is a positive and significant influence between customer satisfaction and customer loyalty.There is a positive and significant influence between service quality, price and customer satisfaction with customer loyalty.
\end{abstract}

Keywords : Service Quality, Price, Customer Satisfaction, Customer Loyalty.

\section{Latar Belakang}

Globalisasi membawa dampak yang sangat besar bagi perkembangan dunia bisnis di seluruh dunia. Pasar terbuka luas dan peluang menjadi semakin lebar. Namun sebaliknya persaingan menjadi semakin ketat dan sulit diprediksikan. Kondisi ini menuntut setiap perusahaan untuk menciptakan keunggulan kompetitif bisnisnya agar mampu bersaing secara berkesinambungan dengan perusahaan-perusahaan lain yang berkecimpung dalam bidang yang sama.

Aktivitas sektor perdagangan akhir-akhir ini terus meningkat dan memberikan dampak pada kegiatan pasar Internasional yang juga terus berkembang pesat.Berbeda dengan perdagangan domestik, perdagangan Internasional ini melibatkan dua negara atau lebih dalam kegiatannya, yang dalam pelaksanaannya harus memenuhi peraturan-peraturan yang ditetapkan oleh masing-masing negara. Perdagangan yang melibatkan negara lain atau yang lebih dikenal dengan istilah ekspor-impor ini memegang peranan yang sangat penting dalam kehidupan bisnis di Indonesia. Tidak saja ditinjau dari segi lalu lintas devisa, melainkan juga atas sumbangannya kepada pendapatan nasional. Untuk itu peranan pemerintah juga dibutuhkan untuk peningkatan jumlah ekspor. 
Semakin banyaknya pengusaha yang melakukan kegiatan ekspor, maka hal ini juga memberikan dampak pada bisnis freight forwarding yang juga ikut berkembang secara pesat. Hal ini disebabkan karena dalam era perdagangan Internasional sekarang ini, arus barang masuk dan keluar sangat cepat. Maka untuk memperlancar bisnis mereka, para pengusaha dituntut untuk memiliki pengetahuan yang cukup mengenai prosedur ekspor dan impor, baik dari segi peraturan yang selalu di update terutama yang berhubungan dengan informasi perdagangan Internasional, kepabeanan, shipping maupun perbankan yang semuanya iniberkaitan antara satu sama lain dan hal ini sangat sering terjadi permasalahan di lapangan.

Tingginya persaingan dunia forwarder, memiliki nama besar dan armada yang banyak tidaklah cukup. Standar kebutuhan pelanggan selalu meningkat setiap saat. PT. Sunggong Logistics adalah salah satu nama besar yang sadar akan hal itu. PT. Sunggong Logistics juga selalu meningkatkan performa pelayanan yang baik dan harga dari produk yang di tawarkan perusahaan untuk kepuasan para pelanggannya yang diharapkan akan berdampak baik bagi perusahaan dikemudian hari.

Keberhasilan suatu perusahaan dipengaruhi oleh bagaimana perusahaan memuaskan pelanggan. Kepuasan pelanggan secara individu sangat sulit dicapai karena keanekaragaman keinginan pelanggan itu sendiri. Oleh karena itu, pelayanan kepada konsumen hendaknya diarahkan kepada pelayanan yang berkesinambungan. Kepuasan pelanggan sangat penting bagi setiap organisasi namun beberapa studi menunjukkan bahwa memuaskan pelanggan saja tidak cukup karena tidak ada jaminan bahwa pelanggan yang puas akan menjadi pelanggan yang loyal.

Loyalitas pelanggan merupakan wujud nyata dari seorang pelanggan yang merasa puas akan kinerja perusahaan. Oleh karena itu, perusahaan dituntut untuk bisa memberikan kinerja yang sesuai atau bahkan melebihi ekspektasi pelanggan agar kepuasan pelanggan dapat tercipta. Adapun faktor-faktoryang dapat mempengaruhi loyalitas pelanggan diantaranya adalah kualitas pelayanan dan harga.

Kualitas pelayanan merupakan ukuran seberapa bagus tingkat layanan yang diberikan mampu sesuai dengan ekspektasi pelanggan.Harga juga turut mengambil peran dalam terciptanya kepuasan pelanggan. Harga itu sendiri menurut Philip Kotler dan Gary Armstrong (2007 : 439) adalah sejumlah nilai yang diberikan atas suatu produk, atau jumlah dari nilai yang ditukar pelanggan atas manfaat-manfaat karena memilikiatau menggunakan produk tersebut.

Fenomena yang ditemukan di lapangan selama penulis melakukan observasi di perusahaan tersebut yaitu, adanya beberapa keluhan pelanggan tentang kualitas pelayanan dan tidak sedikit keluhan konsumen mengenai harga dari PT. Sunggong Logistics.

Oleh karena itu, peneliti tertarik mengangkat tema pengaruh kualitas pelayanan dan harga terhadap loyalitas pelaggan dan kepuasan pelanggan. Menurut penelitian sebelumnya oleh Ahmad Ghufrony (2016) yang berjudul "Pengaruh Kualitas Pelayanan dan Harga Terhadap Kepuasan dan Loyalitas Pelanggan Pada Toko Retail Bahan-Bahan Bangunan Di Kecamatan Dungkek" meneumkan fakta bahwa terdapat pengaruh yang signifikan dan positif antara Kualitas Pelayanan $\left(\mathrm{X}_{1}\right)$ Harga $\left(\mathrm{X}_{2}\right)$ Kualitas Pelayanan $\left(\mathrm{X}_{1}\right)$ terhadap Kepuasan Pelanggan $(\mathrm{Y})$ baik scara parsial dan simultan.

Berdasarkan uraian diatas, mengingat pentingnya kualitas pelayanan dan harga terhadap kepuasan dan loyalitas pelanggan pada perusahaan forwarder, maka penulis mengambil judul : Pengaruh Kualitas Pelayanan dan Harga Terhadap Loyalitas Pelanggan Dengan Kepuasan Pelanggan Sebagai Variabel Intervening Pada PT. Sunggong Logistics.

\section{LANDASAN TEORI}

\section{Kualitas Pelayanan}

Menurut Fandy Tjiptono dan Candra (2016 : 115), kualitas pelayanan sebagai kondisi dinamis yang berhubungan dengan produk, jasa, sumber daya manusia, proses, dan lingkungan 
yang memenuhi atau melebihi harapan. Dijelaskan pula dalam Zulian Yamit (2013 : 8), kualitas pelayanan sebagai suatu sikap dan hasil perbandingan pengharapan kualitas jasa pelanggan dengan kinerja perusahaan yang dirasakan pelanggan. Kualitas bukan hanya menekankan pada aspek hasil akhir, yaitu produk dan jasa tetapi juga menyangkut kualitas manusia, kualitas proses dan kualitas lingkungan. Menurut Wyckof dalam Lovelock yang dikutip oleh Fandy Tjiptono, kualitas pelayanan merupakan tingkat keunggulan (excellence) yang diharapkan dan pengendalian atas keunggulan tersebut untuk memenuhi keinginan pelanggan.

Dengan kata lain terdapat dua faktor utama yang mempengaruhi kualitas pelayanan, yaitu layanan yang diharapkan (expected servce) dan layanan yang di persepsikan (percieved service). (Parasuraman, et.al dalam Fandy Tjiptono).

\section{Dimensi Kualitas Pelayanan}

Lima dimensi penentu kualitas pelayanan menurut Fandy Tjiptono (2014 : 282), yaitu :

a. Berwujud (Tangible), yaitu berupa penampilan fisik, peralatan dan berbagai materi yang terlihat dapat dinilai baik.

b. Empati (Emphaty), yaitu kesediaan karyawan dalam menjalin relasi, komunikasi yang baik, perhatian pribadi, dan pemahaman atas kebutuhan individual pelanggan.

c. Daya Tanggap (Responsiveness), yaitu kemauan dan kemampuan dari karyawan memberikan pelayanan secara cepat dan tanggap. Kesigapan para karyawan untuk memenuhi keinginan konsumen dengan tanggap dan ramah.

d. Keandalan (Reliabilty), yaitu kemampuan untuk memberikan layanan dengan segera, akurat, konsisten, dan memuaskan.

e. Jaminan (Assurance), yaitu mencakup pengetahuan, kompetensi, kesopanan, dan sifat dapat dipercaya yang dimiliki para staff mengenai janji yang diberikan, bebas dari bahaya, resiko atau keragu-raguan.

\section{Harga}

Harga merupakan satu-satunya unsur bauran pemasaran yang sifatnya fleksibel, dimana setiap saat dapat berubah-ubah. Harga juga merupakan salah satu faktor persaingan dalam memasarkan produk. Menurut Philip Kotler dan Gary Armstrong (2012 : 345) harga dapat didefinisikan secara sempit sebagai jumlah uang yang ditagihkan untuk suatu produk atau jasa. Atau dapat didefenisikan secara luas harga sebagai jumlah nilai yang ditukarkan konsumen untuk keuntungan memiliki dan menggunakan produk atau jasa yang memungkinkan perusahaan mendapatkan laba yang wajar dengan cara dibayar untuk nilai pelanggan yang diciptakannya. Definisi lain dikemukakan oleh Buchari Alma (2011 : 169), mengemukakan bahwa harga adalah nilai suatu barang yang dinyatakan dengan uang.

Dari dua pendapat para ahli tersebut dapat ditarik kesimpulan bahwa harga adalah nilai suatu barang dalam bentuk uang yang ditukarkan konsumen untuk memiliki dan menggunakan produk atau jasa yang memungkinkan perusahaan mendapatkan laba.

\section{Dimensi Harga}

Menurut Philip Kotler dan Gary Armstrong yang diterjemahkan oleh Bob Sabran (2012 : 52), ada empat ukuran harga yaitu sebagai berikut :

a. Keterjangkaun Harga

b. Kesesuaian harga dengan kualitas produk

c. Kesesuaian harga dengan manfaat

d. Harga sesuai kemampuan atau daya saing harga 


\section{Kepuasan Pelanggan}

Menurut Philip Kotler \&Kevin Lane Keller (2012 : 150), "Satisfaction is a person's feelings of pleasure or dissapointment that result from comparing a product's perceived performance or outcome to expectations. If the performance falls short of expectations, the outcome is dissatisfied. If it matches expectations, the customer is satisfied or delighted". Menurut Fandy Tjiptono (2014 : 353), kepuasan berasal dari bahasa Latin "Satis" yang berarti cukup baik, memadai dan "Facio" yang berarti melakukan atau membuat. Secara sederhana kepuasan bisa diartikan sebagai upaya pemenuhan sesuatu atau membuat sesuatu memadai.

\section{Dimensi Kepuasan Pelanggan}

Menurut Phillip Kotler dan Gary Armstrong (2010 : 120) dimensi kepuasan pelanggan, antara lain :
a. Sistem keluhan dan saran
b. Survei kepuasan pelanggan

\section{Loyalitas pelanggan}

Menurut Philip Kotler dan Kevin Lane Keller (2009 : 138), loyalitas adalah komitmen yang dipegang secara mendalam untuk membeli atau mendukung kembali produk atau jasa yang disukai di masa depan meski pengaruh situasi dan usaha pemasaran berpotensi menyebabkan pelanggan beralih. Loyalitas menurut Fandy Tjiptono (2011 : 481) adalah perilaku pembelian ulang semata mata menyangkut pembelian merek tertentu yang sama secara berulang kali (bisa dikarenakan memang hanya satu satunya merek yang tersedia, merek termurah dan sebagainya).

\section{Ukuran Loyalitas Pelanggan}

Menurut Fandy Tjiptono dan Candra (2012 : 46) loyalitas dapat diukur berdasarkan :
a. Urutan Pilihan
b. Proporsi Pembelian
c. Preferensi
d. Komitmen

\section{Dimensi Loyalitas Pelanggan}

Menurut Philip Kotler dan Kevin Lane Keller (2006 : 57) berikut dimensi loyalitas pelanggan, yaitu :

a. Repeat Purchase, kesetiaan kepada perusahaan.

b. Retention, tahan terhadap pengaruh pemberitaan negatif mengenai perusahaan.

c. Referral, mereferensikan secara total tentang perusahaan.

\section{Hubungan Antar Variabel Kualitas Pelayanan Dengan Kepuasan Pelanggan}

Menurut Fandy Tjiptono dan Candra (2016 : 125) kualitas jasa dapat diwujudkan melalui pemenuhan kebutuhan dan keinginan pelanggan serta ketepatan penyampaiannya dan mengimbangi harapan pelanggan. Dengan demikian, ada dua faktor utama yang mempengaruhi kualitas jasa, yaitu : jasa yang diharapkan (Expected Service) dan jasa yang dirasakan atau dipersepsikan (Perceived Service). Apabila jasa yang dirasakan sesuai dengan yang diharapkan, maka kualitas jasa bersangkutan akan dipersepsikan baik atau positif. Jika persepsi melebihi yang diharapkan, maka kualitas jasa jelek dibandingkan yang diharapkan, maka kualitas jasa dipersepsikan buruk atau negatif. Oleh sebab itu, baik atau buruknya kualitas jasa tergantung pada kemampuan penyedia jasa dalam memenuhi harapan pelanggannya secara konsisten. 


\section{Hubungan Antar Variabel Harga Dengan Kepuasan Pelanggan}

Menurut Philip Kotler dan Gary Armstrong (2012 : 345) harga dapat didefenisikan secara sempit sebagai jumlah uang yang ditagihkan untuk suatu produk atau jasa. Atau dapat didefenisikan secara luas harga sebagai jumlah nilai yang ditukarkan konsumen untuk keuntungan memiliki dan menggunakan produk atau jasa yang memungkinkan perusahaan mendapatkan laba yang wajar dengan cara dibayar untuk nilai pelanggan yang diciptakannya.

Harga yang tinggi menyebabkan perusahaan dapat mengurangi tingkat kesalahan atau mengurangi pemborosan terhadap produk. Suatu produk yang memiliki kualitas adalah produk yang dapat memenuhi kebutuhan dan keinginan sesuai harapan konsumen bahkan dapat melebihi apa yang diharapkan oleh konsumen sehingga konsumen puas. Jika harga yang telah dibeli memenuhi harapan yang di inginkan konsumen, hal ini akan menimbulkan kepuasan bagi konsumen.

\section{Hubungan Antar Variabel Kualitas Pelanggan dan Harga Dengan Kepuasan Pelanggan}

Kualitas jasa atau kualitas pelayanan berkontribusi signifikan bagi penciptaan diferensiasi, positioning, dan strategi bersaing setiap organisasi pemasaran, baik perusahaan manufaktur maupun penyedia jasa (Tjiptono dan Georgeus, 2007 : 109). Kualitas pelayanan adalah model yang menggambarkan kondisi pelanggan dalam membentuk harapan akan layanan dan pengalaman masa lalu. Harga adalah sejumlah uang yang harus diberikan oleh seseorang untuk memperoleh sesuatu barang atau jasa dan harga tersebut terbentuknya di pasar (Alma, 2007:92). Kepuasan konsumen adalah tingkat perasaan seseorang setelah membandingkan kinerja (hasil) yang ia rasakan dibandingkan dengan harapannya ( Lestari, 2014 : 102).

\section{Hubungan Antar Variabel Kualitas Pelayanan Dengan Loyalitas Pelanggan}

Loyalitas menurut Fandy Tjiptono (2011 : 481) adalah perilaku pembelian ulang semata mata menyangkut pembelian merek tertentu yang sama secara berulang kali (bisa dikarenakan memang hanya satu satunya merek yang tersedia, merek termurah dan sebagainya). Kualitas pelayanan mempunyai dampak positif terhadap loyalitas pelanggan. Dengan kualitas pelayanan melebihi harapan pelanggan, pelanggan akan loyal dan memakai pelayanan jasa secara konsisten dan berulang.

\section{Hubungan Antar Variabel Harga Dengan Loyalitas Pelanggan}

Loyalitas pelanggan merupakan wujud nyata dari seorang pelanggan yang merasa puas akan kinerja perusahaan. Oleh karena itu, perusahaan dituntut untuk bisa memberikan kinerja yang sesuai atau bahkan melebihi ekspektasi pelanggan agar kepuasan pelanggan dapat tercipta. Adapun salah satu faktoryang dapat mempengaruhi loyalitas pelanggan diantaranya adalah harga.Harga itu sendiri menurut Philip Kotler dan Gary Armstrong (2007 : 439) adalah sejumlah nilai yang diberikan atas suatu produk, atau jumlah dari nilai yang ditukar pelanggan atas manfaat-manfaat karena memiliki atau menggunakan produk tersebut.

\section{Hubungan Antar Variabel Kepuasan Pelanggan Dengan Loyalitas Pelanggan}

Menurut Philip Kotler dan Kevin Lane Keller (2016 : 153) kepuasan adalah perasaan seseorang senang atau kecewa yang dihasilkan dari membandingkan kinerja suatu produk yang dirasakan dengan harapan jika kinerja suatu produk atau jasa jauh dari harapan, maka pelanggan akan merasa tidak puas atau kecewa. Jika kinerja suatu produk atau jasa sesuai dengan yang diharapkan, maka pelanggan akan puas. Jika kinerja suatu produk atau jasa melebihi dari yang diharapkan, maka pelanggan akan sangat puas dan merasakan kegembiraan.

Kepuasan pelanggan mempunyai peranan penting terhadap loyalitas pelanggan. Karena pelanggan akan loyal kepada suatu produk atau jasa apabila pelanggan mendapatkan kepuasan dari produk atau jasa tersebut. 


\section{Hubungan Antar Variabel Kualitas Pelayanan, Harga dan Kepuasan Pelanggan Dengan Loyalitas Pelanggan}

Loyalitas pelanggan merupakan wujud nyata dari seorang pelanggan yang merasa puas akan kinerja perusahaan. Oleh karena itu, perusahaan dituntut untuk bisa memberikan kinerja yang sesuai atau bahkan melebihi ekspektasi pelanggan agar kepuasan pelanggan dapat tercipta. Adapun faktor-faktoryang dapat mempengaruhi loyalitas pelanggan diantaranya adalah kualitas pelayanan dan harga, menurut Tjiptono, $2004: 145$.

\section{Kerangka Berpikir}

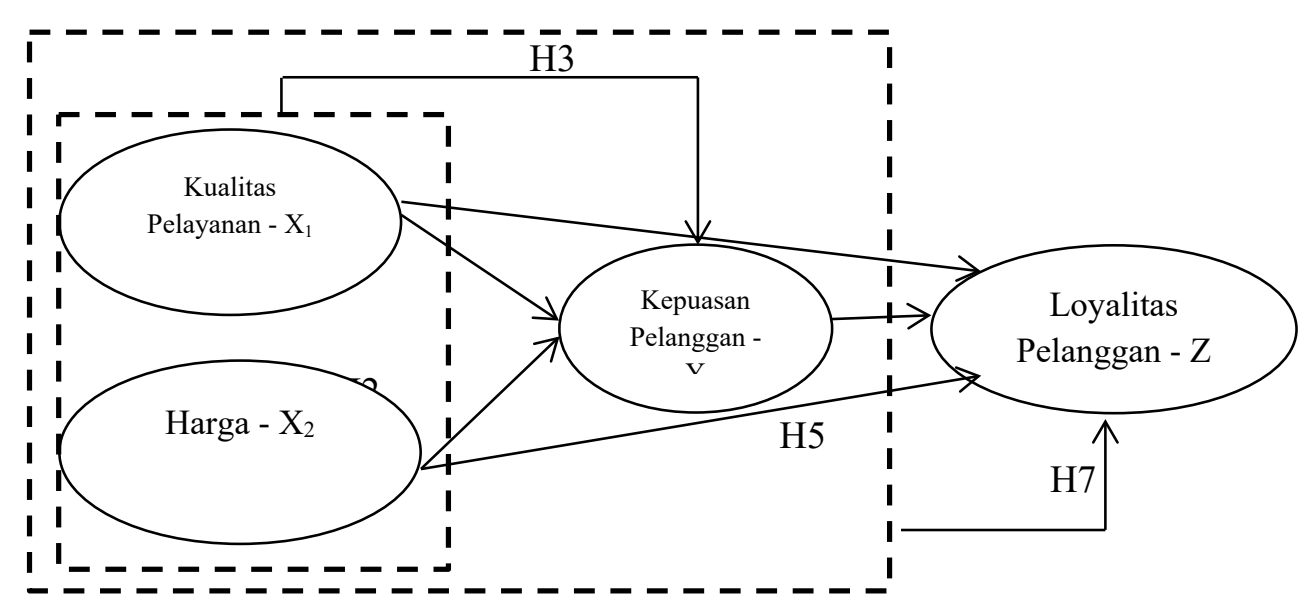

\section{METODOLOGI PENELITIAN}

\section{Waktu dan Tempat}

Penelitian ini dilakukan di kantor PT.Sunngong Logistics yang beralamat di Gedung Pemuda 34 1t.3, Rawamangun, Jakarta Timur.Penelitian ini dilakukan pada bulan Desember 2017.

\section{Desain Penelitian}

Penelitian yang digunakan adalah metode penelitian kuantitatif asosiatif. Sugiyono (2011 :8) menyatakan bahwa penelitian kuantitatif dapat diartikan sebagai metode penelitian yang berlandaskan pada filsafat positivism. Digunakan untuk meneliti pada populasi atau sampel tertenntu, pengumpulan data menggunakan instrumen penelitian, analisis data bersifat kuantitatif atau statistik dengan tujuan untuk menguji hipotesis yang telah ditetapkan. Berdasarkan tujuan dan bentuk permasalahan dalam penelitian ini, maka desain penelitian yang digunakan adalah kausalitas (hubungan antara fenomena yang bersifat sebab akibat).

\section{Definisi Operasional Variabel}

\begin{tabular}{|c|c|c|}
\hline VARIABEL & DIMENSI & INDIKATOR \\
\hline \multirow{5}{*}{$\begin{array}{l}\text { Kualitas Pelayanan }\left(\mathrm{X}_{1}\right) \\
\text { Fandy Tjiptono dan Candra } \\
(2016: 162)\end{array}$} & $\begin{array}{ll}\text { 1. } & \text { Tangibles } \\
\text { (berwujud) }\end{array}$ & $\begin{array}{l}\text { 1. Fasilitas modern. } \\
\text { 2. Sarana komunikasi. }\end{array}$ \\
\hline & 2. Reliability(kehandalan) & $\begin{array}{ll}\text { 1. Ketepatan. } \\
\text { 2. Kemampuan administrasi. }\end{array}$ \\
\hline & $\begin{array}{ll}\text { 3. } & \text { Responsiveness } \\
\text { (daya tanggap) }\end{array}$ & $\begin{array}{l}\text { 1. Pelayanan yang cepat. } \\
\text { 2. Penanganan keluhan. }\end{array}$ \\
\hline & $\begin{array}{ll}\text { 4. } & \text { Assurance } \\
\text { (jaminan) }\end{array}$ & $\begin{array}{ll}\text { 1. Memberikan reward } \\
\text { 2. Keamanan. }\end{array}$ \\
\hline & Empathy & 1. Memberikan perhatian. \\
\hline
\end{tabular}




\begin{tabular}{|c|c|c|}
\hline \multirow{3}{*}{$\begin{array}{l}\text { Harga }\left(X_{2}\right) \\
\text { Philip Kotler }(2012: 134)\end{array}$} & \multirow[b]{2}{*}{ (empati) } & \multirow[b]{2}{*}{ 2. Keramahan karyawan. } \\
\hline & & \\
\hline & 1. $\begin{array}{l}\text { Pernyataan nilai suatu } \\
\text { produk }\end{array}$ & $\begin{array}{ll}\text { 1. Harga terjangkau. } \\
\text { 2. }\end{array}$ \\
\hline & 2. $\quad$ Fleksibel & $\begin{array}{l}\text { 1. Harga sesuai dengan pasar. } \\
\text { 2. } \text { Harga yang kompetitif. }\end{array}$ \\
\hline & 3. Mempengaruhi citra produk & $\begin{array}{ll}\text { 1. } & \text { Kualitas produk. } \\
\text { 2. } & \text { Angsuran. }\end{array}$ \\
\hline \multirow[t]{3}{*}{$\begin{array}{l}\text { Kepuasan Pelanggan (Y) } \\
\text { Kotler dan Amstrong (2010) }\end{array}$} & 1. Re-purchase & $\begin{array}{ll}\text { 1. } & \text { Merasa puas. } \\
\text { 2. } & \text { Tidak tertarik dengan merek lain. }\end{array}$ \\
\hline & 2. Menciptakan word of mouth & $\begin{array}{ll}\text { 1. } & \begin{array}{l}\text { Memberikan informasi kepada } \\
\text { orang lain. }\end{array} \\
\text { 2. } & \text { Mengajak orang lain }\end{array}$ \\
\hline & 3. Menciptakan Citra Merk & $\begin{array}{l}\text { 1. Menanamkan citra merek yang } \\
\text { baik. } \\
\text { 2. Tidak takut kecewa. }\end{array}$ \\
\hline \multirow[t]{3}{*}{$\begin{array}{l}\text { Loyalitas Pelanggan }(\mathrm{Z}) \\
\text { Kotler dan Keller }(2012: 57)\end{array}$} & 1. Re-purchase & $\begin{array}{ll}\text { 1. } & \text { Kesetiaan. } \\
\text { 2. } & \text { Tidak akan tertarik dengan produk } \\
& \text { pesaing. } \\
\end{array}$ \\
\hline & 2. Retention & $\begin{array}{ll}\text { 1. } & \text { Tahan terhadap pemberitaan } \\
\text { negatif. } \\
\text { 2. }\end{array}$ \\
\hline & 3. $\quad$ Referral & $\begin{array}{l}\text { 1. } \text { Mereferensikan secara total. } \\
\text { 2. } \text { Memberikan kesan baik. }\end{array}$ \\
\hline
\end{tabular}

Sumber : diolah oleh peneliti 2018

\section{Populasi dan Sampel}

a. Populasi

Populasi dalam penelitian ini adalah pelanggan PT. Sunggong Logistics bagian Ekspor/Impor dari perusahaan textile, chemical, elektronik dan perusahaan BUMN.

b. Sampel

Karena keterbatasan dana, tenaga dan waktu, maka peneliti menggunakan sampel yang diambil dari populasi. Sampel yang dipakai adalah pengguna jasa produk SOC PT. Sunggong Logistics

c. Teknik Pengumpulan Sampel

Teknik pengumpulan sampel dalam penelitian ini yaitu, teknik pengambilan sampel Probability Sampling yang artinya adalah teknik pengambilan sampel yang memberi peluang atau kesempatan sama bagi setiap unsur atau anggota populasi untuk dipilih menjadi sampel. Sementara sampling yang digunakan adalah random sampling, yaitu sampel diambil secara acak, tanpa memperhatikan tingkatan yang ada dalam populasi. Adapun jumlah sampel yang digunakan sebanyak 100 responden. Jumlah sampel yang digunakan dalam penelitian ini menggunakan rumus Slovin :

$$
\mathrm{n}=\frac{N}{1+N(d)^{2}}
$$

Keterangan :

n : Sampel

$\mathrm{N} \quad$ : Populasi

$d \quad$ : Nilai presisi $95 \%$ atau $\operatorname{sig}=0,05$

Jadi, sampel yang dipakai sebanyak :

$$
\mathrm{n}=\frac{134}{1+134(0,05)^{2}}=100 \text { (jumlah sampel yang digunakan) }
$$




\section{ANALISIS HASIL DAN PEMBAHASAN}

\section{Analisis Deskriptif}

Tabel 4.3

Analisis Deskriptif

Sumber : Hasil Pengolahan Data, 2018

Descriptive Statistics

\begin{tabular}{|l|r|r|r|r|r|r|r|r|r|}
\hline & \multicolumn{1}{|c|}{$\mathrm{N}$} & \multicolumn{1}{c|}{ Range } & \multicolumn{1}{c|}{ Minimum } & \multicolumn{1}{c|}{ Maximum } & \multicolumn{1}{c|}{ Sum } & \multicolumn{2}{|c|}{ Mean } & Std. Deviation & Variance \\
\cline { 2 - 9 } & Statistic & Statistic & Statistic & Statistic & Statistic & Statistic & Std. Error & Statistic & Statistic \\
\hline X1 & 100 & 23 & 26 & 49 & 3729 & 37.29 & .426 & 4.262 & 18.168 \\
X2 & 100 & 12 & 17 & 29 & 2219 & 22.19 & .262 & 2.616 & 6.842 \\
Y & 100 & 13 & 19 & 32 & 2491 & 24.91 & .290 & 2.896 & 8.386 \\
Z & 100 & 20 & 15 & 35 & 2539 & 25.39 & .331 & 3.309 & 10.947 \\
Valid N (listwise) & 100 & & & & & & & & \\
\hline
\end{tabular}

Hasil Analisis Korelasi Antar Variabel

Tabel 4.16

Rangkuman Hasil Analisis Korelasi Antar Variabel

\begin{tabular}{|l|l|l|l|}
\hline Hubungan Antar Variabel & Korelasi & Arah & Hubungan \\
\hline $\mathrm{X}_{1}$ dan $\mathrm{Y}$ & 0,518 & Searah atau positif & Sedang \\
\hline $\mathrm{X}_{2}$ dan $\mathrm{Y}$ & 0,518 & Searah atau positif & Sedang \\
\hline $\mathrm{Y}$ dan $\mathrm{Z}$ & 0,588 & Searah atau positif & Sedang \\
\hline $\mathrm{X}_{1}$ dan $\mathrm{Z}$ & 0,530 & Searah atau positif & Sedang \\
\hline $\mathrm{X}_{2}$ dan $\mathrm{Z}$ & 0,641 & Searah atau positif & Kuat \\
\hline
\end{tabular}

Sumber: Hasil Pengolahan Data, 2018

\section{Analisis Jalur}

Analisis jalur (path analysis) pada penelitian ini akan dibagi menjadi 2 sub-struktur, yaitu sub-struktur 1 dan sub-struktur 2. Analisis ini juga akan menggunakan uji secara individual atau parsial dan juga secara keseluruhan atau simultan. Berikut persamaan yang akan digunakan dalam analisis jalur:

Sub-struktur 1

Variabel kepuasan Pelanggan $(\mathrm{Y})=\rho y x_{1}+\rho y x_{2}+\varepsilon_{1}$

Sub-struktur 2

Variabel Loyalitas Pelanggan $(Z)=\rho z x_{1}+\rho z x_{2}+\rho z y+\varepsilon_{2}$

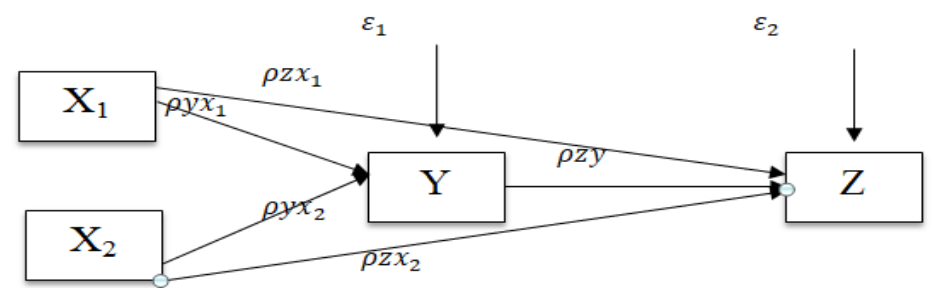

Gambar 4.3 Struktur Pengaruh $\mathbf{X}_{\mathbf{1}}, \mathbf{X}_{\mathbf{2}}, \mathbf{Y}$, dan Z (Sumber : Riduwan dan Kuncoro (2014:6)

\section{Analisis Jalur Sub-Struktur 1}

Analisis jalur antara variabel Kualitas Pelayanan $\left(\mathrm{X}_{1}\right)$, variabel Harga $\left(\mathrm{X}_{2}\right)$ terhadap Kepuasan Pelanggan (Y) akan dijelaskan pada sebuah model gambar yang disebut dengan substruktur 1. 


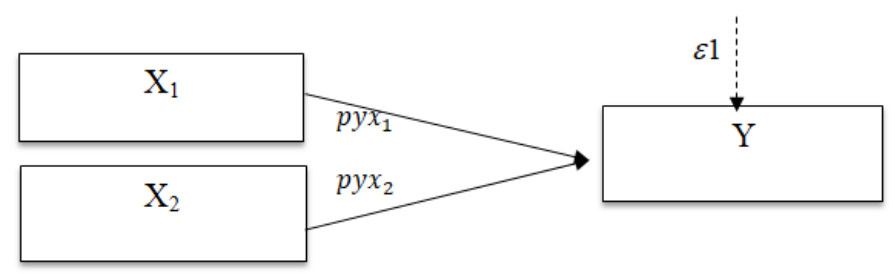

Gambar 4.4. Jalur Sub-struktur1 Sumber: Riduwan dan Kuncoro (2014 : 129)

Pada bagian ini analisis data akan dibagi menjadi dua. Pertama, adalah melihat pengaruh data secara simultan (gabungan atau keseluruhan) dan yang kedua adalah melihat pengaruh secara parsial (individual). Untuk mengetahui hubungan antara variabel kualitas pelayanan $\left(\mathrm{X}_{1}\right)$ dan variabel harga $\left(\mathrm{X}_{2}\right)$ terhadap variabel kepuasan pelanggan $(\mathrm{Y})$ akan dibantu dengan menggunakan program SPSS 20. Kemudian akan muncul output yang menggambarkan tentang hubungan tersebut. Hasil output sub-struktur1 adalah sebagai berikut:

Tabel 4.17 Hasil Pengujian Model Summary Sub-struktur 1

Model Summary

\begin{tabular}{|c|c|c|c|c|c|c|c|c|c|}
\hline \multirow{2}{*}{$\begin{array}{l}\text { Mode } \\
1\end{array}$} & \multirow[t]{2}{*}{$\mathrm{R}$} & \multirow[t]{2}{*}{ R Square } & \multirow{2}{*}{$\begin{array}{l}\text { Adjusted R } \\
\text { Square }\end{array}$} & \multirow{2}{*}{$\begin{array}{l}\text { Std. Error of } \\
\text { the Estimate }\end{array}$} & \multicolumn{5}{|c|}{ Change Statistics } \\
\hline & & & & & $\begin{array}{l}\text { R Square } \\
\text { Change }\end{array}$ & F Change & df1 & df2 & $\begin{array}{c}\text { Sig. F } \\
\text { Change }\end{array}$ \\
\hline 1 & $.588^{\mathrm{a}}$ & .346 & .332 & 2.367 & .346 & 25.610 & 2 & 97 & .000 \\
\hline
\end{tabular}

a. Predictors: (Constant), X2, X1

b. Dependent Variable: Y

Sumber: Hasil Pengolahan Data, 2018

Tabel 4.18 Hasil Pengujian Anova Sub-struktur 1

ANOVA ${ }^{a}$

\begin{tabular}{|cc|c|c|c|c|c|}
\hline \multicolumn{1}{|c|}{ Model } & Sum of Squares & Df & Mean Square & F & Sig. \\
\hline \multirow{4}{*}{1} & Regression & 286.887 & 2 & 143.444 & 25.610 & $.000^{\mathrm{b}}$ \\
& Residual & 543.303 & 97 & 5.601 & & \\
& Total & 830.190 & 99 & & & \\
\hline
\end{tabular}

a. Dependent Variable: Y

b. Predictors: (Constant), X2, X1

Sumber: Hasil Pengolahan Data, 2018

Tabel 4.19 Hasil Pengujian Koefisien Sub-struktur 1

Coefficients $^{\text {a }}$

\begin{tabular}{|c|c|c|c|c|c|c|}
\hline \multirow{2}{*}{\multicolumn{2}{|c|}{ Model }} & \multicolumn{2}{|c|}{ Unstandardized Coefficients } & \multirow{2}{*}{$\begin{array}{c}\text { Standardized } \\
\text { Coefficients } \\
\text { Beta }\end{array}$} & \multirow[t]{2}{*}{$\mathrm{t}$} & \multirow[t]{2}{*}{ Sig. } \\
\hline & & B & Std. Error & & & \\
\hline \multirow{3}{*}{1} & (Constant) & 8.267 & 2.339 & & 3.535 & .001 \\
\hline & $\mathrm{X} 1$ & .226 & .067 & .333 & 3.376 & .001 \\
\hline & $\mathrm{X} 2$ & .370 & .109 & .334 & 3.390 & .001 \\
\hline
\end{tabular}

a. Dependent Variable: Y

Sumber: Hasil Pengolahan Data, 2018 
a. Pengujian Secara Simultan Antara Variabel Kualitas Pelayanan $\left(X_{1}\right)$ dan Variabel Harga $\left(\mathbf{X}_{2}\right)$ dengan Variabel Kepuasan Pelanggan ( $Y$ )

Berdasarkan pada tabel 4.18 Model Summary ${ }^{\mathrm{b}}$ diperoleh nilai $\mathrm{R}_{\text {square }}=0,346$ atau 34,6\%. Ini berarti Kualitas Pelayanan $\left(\mathrm{X}_{1}\right)$ dan Harga $\left(\mathrm{X}_{2}\right)$ mempengaruhi Kepuasan Pelanggan (Y) sebesar 34,6\% dan sisanya sebesar 65,4\% dipengaruhi oleh variabel-variabel diluar penelitian ini. Sementara itu besarnya koefisien jalur bagi variabel lain diluar penelitian yang mempengaruhi nilai variabel.

$$
\begin{aligned}
Y & \left(P_{Y} \varepsilon 1\right)=\sqrt{1-R^{2}} \\
& =\sqrt{ }(1-0,346) \\
& =0,654
\end{aligned}
$$

Sedangkan pada tabel 4.19 Anova Sub-Struktur 1 diperoleh nilai Fhitung sebesar 25,610 lebih besar dari Ftabel 2,70 atau Fhitung $\geq$ Ftabel $=$ Ho ditolak dan Haditerima,dengan nilai probabilitas $(\mathrm{sig})=0,000$ yaitu $0,000 \leq 0,05$, maka keputusannya adalah Ho ditolak dan Ha diterima.Dapat disimpulkan bahwa Kualitas Pelayanan $\left(\mathrm{X}_{1}\right)$ dan Harga $\left(\mathrm{X}_{2}\right)$ berkontribusi secara simultan terhadap Kepuasan Pelanggan (Y) pada PT. Sunggong Logistics. Oleh sebab itu, pengujian secara individual dapat dilakukan

b. Pengujian Secara Parsial Antara Variabel Kualitas Pelayanan $\left(X_{1}\right)$ dengan Variabel Kepuasan Pelanggan (Y)

Berdasarkan tabel 4.20 Coefficients Sub-Struktur 1, uji secara individual dinyatakan bahwa hasil koefisien jalur $\rho y x_{1}=0,333$ didapatkan nilai sig. sebesar $0,001 \leq$ 0,05 dan t-hitung 3,376 $\geq \mathrm{t}$-tabel 1,98, maka Ho ditolak dan Ha diterima yang berarti Kualitas Pelayanan $\left(\mathrm{X}_{1}\right)$ memiliki pengaruh secara parsial terhadap Kepuasan Pelanggan (Y) pada PT. Sunggong Logistics.

c. Pengujian Secara Parsial Antara Variabel Harga $\left(\mathrm{X}_{2}\right)$ dengan Variabel Kepuasan Pelanggan (Y)

Berdasarkan tabel 4.20 Coefficients Sub-Struktur 1, uji secara individual dinyatakan bahwa hasil koefisien jalur $\rho y x_{2}=0,334$ didapatkan nilai sig. sebesar $0,001 \leq$ 0,05 dan t-hitung 3,390 $\geq$ t-tabel 1,98, maka Ho ditolak dan Ha diterima yang berarti Harga $\left(\mathrm{X}_{2}\right)$ memiliki pengaruh secara parsial terhadap Kepuasan Pelanggan (Y) pada PT. Sunggong Logistics.

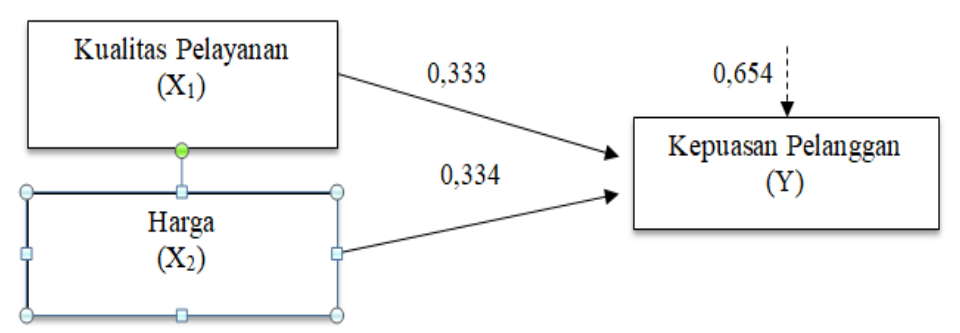

\section{Gambar 4.5. Rangkuman Diagram Jalur Sub-Struktur 1}

Persamaan untuk sub-struktur 1 dalam kerangka hubungan kausal empiris adalah sebagai berikut: $\mathrm{Y}=p y x_{1}+p y x_{2}+\varepsilon_{1}$

$\mathrm{Y}=0,333+0,334+0,654$ dengan $\mathrm{R}^{2}=0,346=34,6 \%$

Dari persamaan sub-struktur 1 di atas, maka dapat dirumuskan sebagai berikut:

1. Kepuasan pelanggan (Y) pada PT. Sunggong Logistics dipengaruhi oleh kualitas pelayanan $\left(\mathrm{X}_{1}\right)$ dan harga $\left(\mathrm{X}_{2}\right)$ secara simultan $34,6 \%$ dan sisanya $65,4 \%$ dipengaruhi oleh faktor lain diluar penelitian. 
2. Setiap peningkatan nilai variabel kualitas pelayanan $\left(\mathrm{X}_{1}\right)$ akan diikuti dengan peningkatan nilai variabel kepuasan pelanggan (Y) sebesar 0,333. Begitu pula sebaliknya, setiap penurunan nilai variabel kualitas pelayanan $\left(\mathrm{X}_{1}\right)$ maka nilai variabel kepuasan pelanggan $(\mathrm{Y})$ akan mengalami penurunan sebesar 0,333 .

3. Setiap peningkatan nilai variabel harga $\left(\mathrm{X}_{2}\right)$ akan diikuti dengan peningkatan nilai variabel kepuasan pelanggan (Y) sebesar 0,334. Begitu juga sebaliknya, setiap penurunan nilai variabel harga $\left(\mathrm{X}_{2}\right)$ maka nilai kepuasan pelanggan $(\mathrm{Y})$ akan mengalami penurunan sebesar 0,334 .

Setelah melakukan penelitian untuk sub-struktur 1 yang memuat tentang analisa pengaruh dan analisa jalur antara variabel kualitas pelayanan $\left(\mathrm{X}_{1}\right)$, harga $\left(\mathrm{X}_{2}\right)$ dan kepuasan pelanggan $(\mathrm{Y})$, langkah selanjutnya yang dilakukan yaitu menyusun sub-struktur 2 yang terdiri dari analisa pengaruh dan analisa jalur pada variabel tersebut ditambah dengan variabel loyalitas pelanggan $(Z)$.

Tabel 4.20 Rangkuman Hasil Koefisien Jalur Sub-Struktur 1

\begin{tabular}{|c|c|c|c|c|c|}
\hline $\begin{array}{c}\text { Pengaruh Antar } \\
\text { Variabel }\end{array}$ & $\begin{array}{c}\text { Koefisien } \\
\text { Jalur }\end{array}$ & $\begin{array}{c}\text { Nilai } \\
\text { Sig. }\end{array}$ & Hasil Pengujian & $\begin{array}{c}\text { Koefisien } \\
\text { Determinasi }\end{array}$ & $\begin{array}{c}\text { Koefisien } \\
\text { Variabel lain } \\
(p y \varepsilon 1)\end{array}$ \\
\hline $\mathrm{X}_{1}$ terhadap Y & 0,333 & 0,001 & \multirow{2}{*}{ Ho ditolak Ha diterima } & $0,346=34,6 \%$ & 0,654 \\
\hline $\mathrm{X}_{2}$ terhadap Y & 0,334 & 0,001 & & \\
\hline
\end{tabular}

Sumber : Hasil Pengolahan Data, 2018

\section{Analisis Jalur Sub-struktur 2}

Setelah sebelumnya melakukan pengujian sub-struktur 1, tahap selanjutnya adalah melakukan pengujian sub-struktur 2. Pengujian sub-struktur 2 ini terdiri dari Kualitas Pelayanan $\left(\mathrm{X}_{1}\right)$, Harga $\left(\mathrm{X}_{2}\right)$, Kepuasan Pelanggan $(\mathrm{Y})$, dan Loyalitas Pelanggan $(\mathrm{Z})$. Sub-struktur 2 dapat digambarkan dalam bentuk kerangka seperti pada gambar di bawah berikut ini:

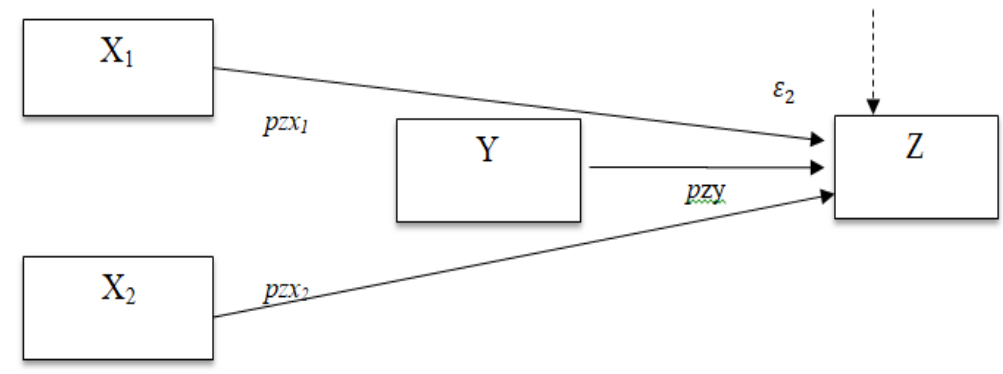

Gambar 4.6 Jalur Sub-Struktur 2

Sub-struktur 2 akan dianalisa menggunakan analisis jalur dengan persamaan strukturalnya adalah $Z=\rho z x_{1}+\rho z x_{2}+\rho z y+\varepsilon_{2}$. Dengan menggunakan SPSS 20, berikut hasil dari analisis jalur untuk sub-struktur 2 : 
Tabel 4.21 Hasil Pengujian Model Summary Sub-struktur 2

\section{Model Summary}

\begin{tabular}{|c|c|c|c|c|c|c|c|c|c|}
\hline \multirow{2}{*}{$\begin{array}{l}\text { Mod } \\
\text { el }\end{array}$} & \multirow[t]{2}{*}{$\mathrm{R}$} & \multirow{2}{*}{$\begin{array}{c}\mathrm{R} \\
\text { Square }\end{array}$} & \multirow{2}{*}{$\begin{array}{l}\text { Adjusted } \\
\text { R Square }\end{array}$} & \multirow{2}{*}{$\begin{array}{l}\text { Std. Error } \\
\text { of the } \\
\text { Estimate }\end{array}$} & \multicolumn{5}{|c|}{ Change Statistics } \\
\hline & & & & & $\begin{array}{l}\text { R Square } \\
\text { Change }\end{array}$ & $\begin{array}{c}\mathrm{F} \\
\text { Change }\end{array}$ & dfl & $\mathrm{df} 2$ & $\begin{array}{c}\text { Sig. F } \\
\text { Change }\end{array}$ \\
\hline 1 & $.718^{\mathrm{a}}$ & .515 & .500 & 2.340 & .515 & 33.963 & 3 & 96 & .000 \\
\hline
\end{tabular}

a. Predictors: (Constant), Y, X1, X2

b. Dependent Variable: Z

Sumber : Hasil Pengolahan Data, 2018

Tabel 4.22 Hasil Pengujian Anova Sub-struktur 2

ANOVA $^{\mathrm{a}}$

\begin{tabular}{|rl|r|r|r|r|r|}
\hline \multicolumn{1}{|l|}{ Model } & Sum of Squares & Df & Mean Square & F & \multicolumn{1}{c|}{ Sig. } \\
\hline \multirow{3}{*}{1} & Regression & 558.018 & 3 & 186.006 & 33.963 & $.000^{\mathrm{b}}$ \\
& Residual & 525.772 & 96 & 5.477 & & \\
& Total & 1083.790 & 99 & & & \\
\hline
\end{tabular}

a. Dependent Variable: Z

b. Predictors: (Constant), Y, X1, X2

Sumber : Hasil Pengolahan Data, 2018

Tabel 4.23 Hasil Pengujian Koefisien Sub-struktur 2

Coefficients $^{\mathrm{a}}$

\begin{tabular}{|c|c|c|c|c|c|c|}
\hline \multirow{2}{*}{\multicolumn{2}{|c|}{ Model }} & \multicolumn{2}{|c|}{ Unstandardized Coefficients } & Standardized & \multirow[t]{2}{*}{$\mathrm{T}$} & \multirow[t]{2}{*}{ Sig. } \\
\hline & & B & Std. Error & Beta & & \\
\hline \multirow{4}{*}{1} & (Constant) & 1.158 & 2.457 & & .471 & .638 \\
\hline & $\mathrm{X} 1$ & .118 & .070 & .152 & 1.685 & .095 \\
\hline & $\mathrm{X} 2$ & .508 & .114 & .401 & 4.447 & .000 \\
\hline & Y & .344 & .100 & .301 & 3.426 & .001 \\
\hline
\end{tabular}

a. Dependent Variable: $Z$

Sumber : Hasil Pengolahan Data, 2018

a. Pengujian secara simultan Kualitas Pelayanan $\left(X_{1}\right)$, Harga $\left(X_{2}\right)$, dan Kepuasan Pelanggan (Y) terhadap Loyalitas Pelanggan (Z).

Berdasarkan tabel pada tabel 4.22 Model Summary ${ }^{\mathrm{b}}$ Sub-struktur 2 diperoleh nilai $\mathrm{R}_{\text {square }}=0,515$ atau 51,5\% Ini berarti Kualitas Pelayanan $\left(\mathrm{X}_{1}\right)$, Harga $\left(\mathrm{X}_{2}\right)$ dan Kepuasan Pelanggan (Y) mempengaruhi Loyalitas Pelanggan (Z) sebesar 51,5\% dan sisanya sebesar $48,5 \%$ dipengaruhi oleh variabel-variabel diluar penelitian ini. Sementara itu besarnya koefisien jalur bagi variabel lain diluar penelitian yang mempengaruhi nilai variabel

$$
\begin{aligned}
& \left(\mathrm{P}_{\mathrm{Y} \varepsilon_{2}}\right)=\sqrt{1-R^{2}} \\
& =\sqrt{ }(1-0,515) \\
& =0,485
\end{aligned}
$$


Sedangkan pada tabel 4.23 Anova Sub-Struktur 2 diperoleh nilai Fhitung sebesar 33,963 lebih besar dari Ftabel 2,70 atau Fhitung $\geq$ Ftabel $=$ Ho ditolak dan Ha diterima, dengan nilai probabilitas (sig) $=0,000$ yaitu $0,000 \leq 0,05$, maka keputusannya adalah Ho ditolak dan Ha diterima. Dapat disimpulkan bahwa Kualitas Pelayanan (X1), Harga (X2) dan Kepuasan Pelanggan (Y) berkontribusi secara simultan terhadap Loyalitas Pelanggan (Z) pada PT. Sunggong Logistics. Oleh sebab itu, pengujian secara individual dapat dilakukan.

b. Pengujian Secara Parsial Antara Variabel Kualitas Pelayanan $\left(X_{1}\right)$ dengan Variabel Loyalitas Pelanggan (Z)

Berdasarkan tabel 4.24 Coefficients Sub-Struktur 2, uji secara individual dinyatakan bahwa hasil koefisien jalur $\rho z x_{1}=0,152$ didapatkan nilai sig. sebesar $0,095 \geq$ 0,05 dan t-hitung 1,685 $\leq \mathrm{t}$-tabel 1,98, maka Ho diterima dan Ha ditolak yang berarti Kualitas Pelayanan $\left(\mathrm{X}_{1}\right)$ tidak memiliki pengaruh secara parsial terhadap Loyalitas Pelanggan $(Z)$ pada PT. Sunggong Logistics.

c. Pengujian Secara Parsial Antara Variabel Harga $\left(X_{2}\right)$ dengan Variabel Loyalitas Pelanggan (Z)

Berdasarkan tabel 4.24 Coefficients Sub-Struktur 2, uji secara individual dinyatakan bahwa hasil koefisien jalur $\rho \mathrm{x}_{2}=0,401$ didapatkan nilai sig. sebesar $0,000 \leq$ 0,05 dan t-hitung 4,447 $\geq \mathrm{t}$-tabel 1,98, maka Ho ditolak dan Ha diterima yang berarti Harga $\left(\mathrm{X}_{2}\right)$ memiliki pengaruh secara parsial terhadap Loyalitas Pelanggan $(\mathrm{Z})$ pada PT. Sunggong Logistics.

d. Pengujian Secara Parsial Antara Variabel Kepuasan Pelanggan (Y) dengan Variabel Loyalitas Pelanggan (Z)

Berdasarkan tabel 4.24 Coefficients Sub-Struktur 2, uji secara individual dinyatakan bahwa hasil koefisien jalur $\rho y x_{2}=0,301$ didapatkan nilai sig. sebesar $0,001 \leq$ 0,05 dan t-hitung 3,426 $\geq$ t-tabel 1,98, maka Ho ditolak dan Ha diterima yang berarti Kepuasan Pelanggan (Y) memiliki pengaruh secara parsial terhadap Loyalitas Pelanggan (Z) pada PT. Sunggong Logistics.

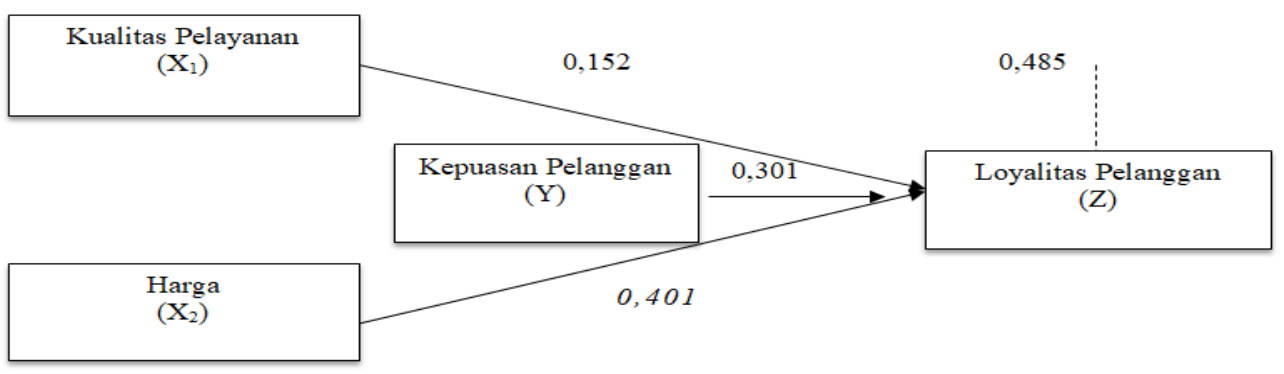

\section{Gambar 4.7 Rangkuman Diagram Jalur Sub-Struktur 2}

Persamaan untuk sub-struktur 2 dalam kerangka hubungan kausal empiris sebagai berikut:

$$
\begin{aligned}
& \mathrm{Z}=\rho_{z x 1}+\rho_{z x 2}+\rho_{z y}+\varepsilon_{2} \\
& \mathrm{Z}=0,152+0,401+0,301+0,485 \text { Dengan } \mathrm{R}^{2}=0,515=51,5 \%
\end{aligned}
$$

Dari persamaan sub-struktur 2 di atas, maka dapat dirumuskan sebagai berikut:

1) Loyalitas pelanggan ( $\mathrm{Z}$ ) dipengaruhi oleh Kualitas Pelayanan $\left(\mathrm{X}_{1}\right)$, Harga (X2), dan Kepuasan Pelanggan (Y) secara simultan sebesar 51,5\% dan sisanya sebesar 48,5\% dipengaruhi oleh faktor lain di luar penelitian ini. 
2) Setiap peningkatan nilai variabel Kualitas Pelayanan $\left(X_{1}\right)$ akan diikuti peningkatan nilai variabel Loyalitas Pelanggan $(Z)$ sebesar 0,152. Begitu juga sebaliknya, setiap penurunan nilai variabel Kualitas Pelayanan $\left(\mathrm{X}_{1}\right)$ maka nilai variabel Loyalitas Pelanggan $(Z)$ akan mengalami penurunan sebesar 0,152 .

3) Setiap peningkatan nilai variabel Harga $\left(\mathrm{X}_{2}\right)$ akan diikuti peningkatan nilai variabel Loyalitas Pelanggan $(Z)$ sebesar 0,401. Begitu juga sebaliknya, setiap penurunan Harga $\left(X_{2}\right)$ maka Loyalitas Pelanggan $(Z)$ akan mengalami penurunan sebesar 0,401 .

4) Setiap peningkatan nilai variabel Kepuasan Pelanggan (Y) akan diikuti peningkatan nilai variabel Loyalitas Pelanggan $(Z)$ sebesar 0,301. Begitu juga sebaliknya, setiap penurunan Kepuasan Pelanggan (Y) maka Loyalitas Pelanggan (Z) akan mengalami penurunan sebesar 0,301 .

Tabel 4.24. Rangkuman Hasil Koefisien Jalur Sub-Struktur 2

\begin{tabular}{|l|c|c|l|c|c|}
\hline $\begin{array}{c}\text { Pengaruh antar } \\
\text { Variabel }\end{array}$ & $\begin{array}{c}\text { Koefisien } \\
\text { Jalur }\end{array}$ & $\begin{array}{c}\text { Nilai } \\
\text { Sig. }\end{array}$ & Hasil Pengujian & $\begin{array}{c}\text { Koefisien } \\
\text { Determinasi }\end{array}$ & $\begin{array}{c}\text { Koefisien Variabel } \\
\text { lain }\left(p y \varepsilon_{2}\right)\end{array}$ \\
\hline $\mathrm{X}_{1}$ terhadap Z & 0,152 & 0,095 & $\begin{array}{l}\mathrm{H}_{\mathrm{o}} \text { diterima Ha } \\
\text { ditolak }\end{array}$ & \multirow{2}{*}{0,485} \\
\cline { 1 - 4 } $\mathrm{X}_{2}$ terhadap Z & 0,401 & 0,000 & $\begin{array}{l}\mathrm{H}_{\mathrm{o}} \text { ditolak Ha } \\
\text { diterima }\end{array}$ & $0,515=51,5 \%$ & \\
\cline { 1 - 4 } Y terhadap Z & 0,301 & 0,001 & $\begin{array}{l}\mathrm{H}_{\mathrm{o}} \text { ditolak Ha } \\
\text { diterima }\end{array}$ & \\
\hline
\end{tabular}

Sumber : Hasil Pengolahan Data, 2018

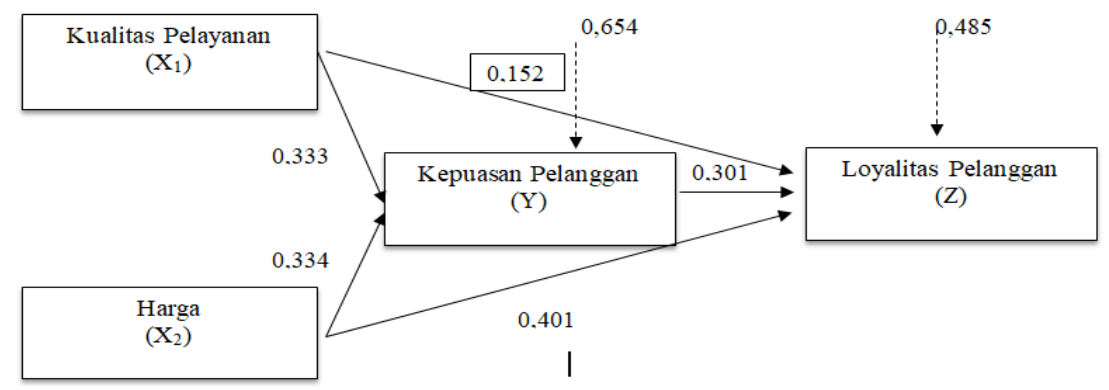

Gambar 4.8 Besar Pengaruh Antar Variabel $X_{1}, X_{2}, Y, Z$

Tabel 4.25 Rangkuman Koefisien Jalur

\begin{tabular}{|c|c|c|c|c|c|}
\hline \multirow[b]{2}{*}{ Variabel } & \multirow[b]{2}{*}{$\begin{array}{l}\text { Koefisien } \\
\text { Jalur }\end{array}$} & \multicolumn{3}{|c|}{ Pengaruh } & \multirow[b]{2}{*}{$\begin{array}{c}\text { Pengaruh } \\
\text { Bersama }\left(\mathrm{R}^{2}\right)\end{array}$} \\
\hline & & Langsung & $\begin{array}{c}\text { Tidak Langsung } \\
\text { (Melalui Variabel Y) }\end{array}$ & Total & \\
\hline $\mathrm{X}_{1}$ terhadap $\mathrm{Y}$ & 0,333 & 0,333 & - & 0,333 & - \\
\hline $\mathrm{X}_{2}$ terhadap $\mathrm{Y}$ & 0,334 & 0,334 & - & 0,334 & - \\
\hline $\mathrm{X}_{1}$ terhadap $\mathrm{Z}$ & 0,152 & 0,152 & $0,152 \times 0,301=0,045$ & 0,197 & - \\
\hline $\mathrm{X}_{2}$ terhadap $\mathrm{Z}$ & 0,401 & 0,401 & $0,401 \times 0,301=0,120$ & 0,521 & - \\
\hline Y terhadap $\mathrm{Z}$ & 0,301 & 0,301 & - & 0,301 & - \\
\hline$\varepsilon_{1}$ & 0,654 & - & - & - & - \\
\hline$\varepsilon_{2}$ & 0,485 & - & - & - & - \\
\hline $\mathrm{X}_{1}$ dan $\mathrm{X}_{2}$ terhadap $\mathrm{Y}$ & - & - & - & - & $0,346=34,6 \%$ \\
\hline $\begin{array}{c}\mathrm{X}_{1} \text { dan } \mathrm{X}_{2} \text { terhadap } \mathrm{Z} \\
\text { melalui } \mathrm{Y}\end{array}$ & - & - & - & - & $0,515=51,5 \%$ \\
\hline
\end{tabular}

Sumber: Hasil Pengolahan Data, 2018 


\section{Pembahasan}

Dari hasil penelitian yang telah dilakukan,hal-hal yang mempengaruhi Loyalitas Pelanggan padaPT. Sunggong Logistics sebagai berikut :

\section{Hasil Penelitian Dengan Landasan Teori}

\section{a. Hubungan Kualitas Pelayanan dengan Kepuasan Pelanggan}

Dari hasil pengujian alat analisis pada penelitian ini menunjukan bahwa variabel kualitas pelayanan berpengaruh terhadap kepuasan pelanggan. Dalam mendapatkan sebuah kepuasan pelanggan dalam jasa, kualitas pelayanan tentu diperlukan demi kelangsungan hidup perusahaan.

Sesuai dengan teori yang dikemukakan oleh Fandy Tjiptono dan Candra (2016 : 125) bahwa kualitas jasa dapat diwujudkan melalui pemenuhan kebutuhan dan keinginan pelanggan serta ketepatan penyampaiannya dan mengimbangi harapan pelanggan. Oleh sebab itu, baik atau buruknya kualitas jasa tergantung pada kemampuan penyedia jasa dalam memenuhi harapan pelanggannya secara konsisten.

\section{b. Hubungan Harga dengan Kepuasan Pelanggan}

Dari hasil pengujian alat analisis pada penelitian ini menunjukan bahwa variabel harga juga berpengaruh terhadap kepuasan pelanggan. Dalam mendapatkan sebuah kepuasan pelanggan perusahaan jasa,harga tentu menjadi pertimbangan.

Menurut Philip Kotler dan Gary Armstrong (2012 : 345) bahwa harga dapat didefenisikan secara luassebagai jumlah nilai yang ditukarkan konsumen untuk keuntungan memiliki dan menggunakan produk atau jasa dengan cara dibayar untuk nilai pelanggan yang diciptakannya. Jadi, tinggi rendahnya harga dari jasa PT. Sunggong Logistics sangat berpengaruh pada tingkat kepuasan konsumen.

\section{c. Hubungan Kualitas Pelayanan dan Harga dengan Kepuasan Pelanggan}

Dari hasil pengujian alat analisis pada penelitian ini menunjukan bahwa variabel kualitas pelayanan dan harga secara simultan berpengaruh terhadap kepuasan pelanggan.Sesuai dengan teori Lestari, 2014 : 102 bahwa kepuasan pelanggan adalah tingkat perasaan seseorang setelah membandingkan kinerja (hasil) yang ia rasakan dibandingkan dengan harapannya. Apabila kualitas pelayanan di PT. Sunggong baik dengan harga yang terjangkau, maka nilai kepuasan pelanggan akan bertambah dan begitupun sebaliknya.

\section{d. Hubungan Kualitas Pelayanan dengan Loyalitas Pelanggan}

Dari hasil pengujian alat analisis pada penelitian ini menunjukan bahwa variabel kualitas pelayanan tidak berpengaruh secara langsung terhadap loyalitas pelanggan. Dengan kata lain, loyalitas pelanggan dapat dipengaruhi dari variabel diluar penelitian ini. Faktorfaktor yang dapat mempengaruhi loyalitas pelanggan menurut Vanessa Gaffar (2007 : 72) seperti : kepuasan, ikatan emosional, kepercayaan, kemudahan dan pengalaman dengan perusahaan.

\section{e. Hubungan Harga dengan Loyalitas Pelanggan}

Dari hasil pengujian alat analisis pada penelitian ini menunjukan bahwa variabel harga berpengaruh langsung terhadap loyalitaspelanggan.Hal ini bisa menjadi pertimbangan untuk perusahaan jasa mengenai penetapan harga supaya pelanggan tetap loyal terhadap 
perusahaan. Loyalitas menurut Fandy Tjiptono (2011 : 481) adalah perilaku pembelian ulang semata mata menyangkut pembelian merek tertentu yang sama secara berulang kali (bisa dikarenakan memang hanya satu satunya merek yang tersedia, merek termurah dan sebagainya).

\section{f. Hubungan Kepuasan Pelanggan dengan Loyalitas Pelanggan}

Dari hasil pengujian alat analisis pada penelitian ini menunjukan bahwa variabel kepuasan pelanggan berpengaruh terhadap loyalitas pelanggan. Kepuasan pelanggan pada perusahaan sangat diperlukan. Apabila pelanggan merasa puas mereka akan menjadi loyal terhadap perusahaan. Sesuai dengan yg dikemukakan oleh Philip Kotler dan Kevin Lane Keller (2016 : 153) bahwa kepuasan adalah perasaan seseorang senang atau kecewa yang dihasilkan dari membandingkan kinerja suatu produk yang dirasakan dengan harapan jika kinerja suatu produk atau jasa jauh dari harapan, maka pelanggan akan merasa tidak puas atau kecewa. Jika kinerja suatu produk atau jasa sesuai dengan yang diharapkan, maka pelanggan akan puas. Jika kinerja suatu produk atau jasa melebihi dari yang diharapkan, maka pelanggan akan sangat puas dan merasakan kegembiraan.

\section{g. Hubungan Kualitas Pelanggan, Harga dan Kepuasan Pelangggan dengan Loyalitas Pelanggan}

Dari hasil pengujian alat analisis pada penelitian ini menunjukan bahwa variabel kualitas pelayanan, harga dan kepuasan pelanggan berpengaruh terhadap loyalitas pelanggan. Nilai dari kualitas pelayanan, harga dan kepuasan pelanggan pada perusahaan sangatlah berpengaruh pada tingkat loyalitas pelanggan. Apabila pelanggan merasa puasdengan kualitas pelayanan dan harga yang ditawarkan PT. Sunggong Logistics, sudah pasti konsumenakan menjadi loyal terhadap perusahaan. Sesuai dengan pendapat Tjiptono, 2004 : 145 yang mengemukakanbahwa faktor-faktoryang dapat mempengaruhi loyalitas pelanggan diantaranya adalah kualitas pelayanan dan harga.

\section{Hasil Penelitian Dengan Penelitian Terdahulu}

\section{a. Hubungan Kualitas Pelayanan dan Kepuasan Pelanggan}

Dari hasil pengujian alat analisis pada penelitian ini menunjukan bahwa variabel kualitas pelayanan berpengaruh terhadap kepuasan pelanggan. Penelitian ini sesuai yang dilakukan oleh Olive Caroline dan Candra Kuswoyo (2013) dalam judul Pengaruh Kualitas Pelayanan dan Harga Terhadap Loyalitas Pelanggan Melalui Kepuasan Pelanggan Hotel Zodiak Di Kota Bandung.

\section{b. Hubungan Harga dan Kepuasan Pelanggan}

Dari hasil pengujian alat analisis pada penelitian ini menunjukan bahwa variabel harga berpengaruh terhadap kepuasan pelanggan. Penelitian ini sesuai dengan yang dilakukan oleh Ahmad Ghufrony (2016) yang berjudul Pengaruh Kualitas Pelayanan dan Harga Terhadap Kepuasan dan Loyalitas Pelanggan Pada Toko Retail Bahan-Bahan Bangunan di Kecamatan Dungkek.

\section{c. Hubungan Kualitas Pelayanan dan Loyalitas Pelanggan}

Dari hasil pengujian alat analisis pada penelitian ini menunjukan bahwa variabel kualitas pelayanan tidak berpengaruh terhadap loyalitas pelanggan. Penelitian ini sesuai 
dengan yang dilakukan oleh Annisa Eri Pratiwi(2017) yang berjudul Pengaruh Kualitas Pelayanan dan Kepercayaan Terhadap Loyalitas Pelanggan Dengan Kepuasan Pelanggan Sebagai Variabel Intervening (Studi Kasus Pada DNI SKIN CENTER Cabang Bintaro).

\section{d. Hubungan Harga dan Loyalitas Pelanggan}

Dari hasil pengujian alat analisis pada penelitian ini menunjukan bahwa variabel harga berpengaruh terhadap loyalitas pelanggan.Penelitian ini sesuai dengan yang dilakukan oleh Padma T Wibawa, Naili Farida, Sari Listyorini (2014). Pengaruh Kualitas Pelayanan, Harga dan Promosi Terhadap Loyalitas Pelanggan Melalui Kepuasan Pelanggan PT. Matahari Silverindo Jaya Semarang.

\section{e. Hubungan Kepuasan Pelanggan dan Loyalitas Pelanggan}

Dari hasil pengujian alat analisis pada penelitian ini menunjukan bahwa variabel kualitas pelayananberpengaruh terhadap loyalitaspelanggan. Hasil penelitian ini sesuai dengan dilakukan oleh Olive Caroline dan Candra Kuswoyo (2013) dengan judul Pengaruh Kualitas Pelayanan dan Harga Terhadap Loyalitas Pelanggan Melalui Kepuasan Pelanggan Hotel Zodiak di Kota Bandung.

\section{Kesimpulan}

Berdasarkan hasil yang sudah dilakukan tentang Kualitas Pelayanan dan Harga terhadap Loyalitas Pelanggan dengan Kepuasan Pelanggan sebagai Variabel Intervening pada PT. Sunggong Logistics dapat disimpulkanbahwa :

a. Kualitas pelayanan berpengaruh signifikan terhadap kepuasan pelanggan PT. Sunggong Logistics.

b. Harga berpengaruh signifikan terhadap kepuasan pelanggan PT. Sunggong Logistics.

c. Kualitas pelayanan dan harga secara simultan berpengaruh signifikan terhadap kepuasan pelanggan PT. Sunggong Logistics.

d. Kualitas pelayanan tidak berpengaruh secara langsung yang signifikan terhadap loyalitas pelanggan PT. Sunggong Logistics.

e. Harga berpengaruh signifikan terhadap loyalitas pelanggan PT. Sunggong Logistics.

f. Kepuasan pelanggan berpengaruh signifikan terhadap loyalitas pelanggan PT. Sunggong Logistics.

g. Kualitas pelayanan, harga, dan kepuasan pelanggan secara simultan berpengaruh signifikan terhadap loyalitas pelanggan PT. Sunggong Logistics.

\section{Daftar Pustaka}

Kotler, Philip dan Kevin Lane Keller. 2016. Marketing Management (GlobalEdition) $15^{\text {Th }}$ Edition. New Jersey: Person.

Tjiptono,Fandy dan Gregorius Chandra. 2016. Service, Quality \& Satisfaction Edisi 4. Yogyakarta: Andi

Sugiyono. 2014. “Metode Penelitian Kuantitatif, Kualitatif dan R\&D”.Bandung : Alfabeta.

Mursid, M, Drs. 2014. "Manajemen Pemasaran”. Bumi Aksara

Riduwan, Dr. dan Engkos Ahmad Kuncoro. 2014. "Cara MudahMenggunakan dan Memaknai Path Analysis (Analisis Jalur)".Bandung : Alfabeta.

Tjiptono,Fandy dan Gregorius Chandra. 2014. Strategi Pemasaran, Penerbit. Andy, Yogyakarta

Priyatno, Duwi. 2014. "SPSS 22 : Pengolahan Data Terpraktis".

Yogyakarta : Andi. 
Riduwan dan Engkos Ahmad Kuncoro. 2014. Cara Mudah Menggunakan danMemaknai Path Analysis (Analisis Jalur). Bandung: Alfabeta.

Lupiyoadi, Rambat. 2013. "Manajemen Pemasaran Jasa”. Jakarta :Salemba Empat.

Siregar, Syofian. 2013. "Metode Penelitian Kuantitatif". Jakarta : Prenada Media Group.

Kotler, Philip dan G. Amstrong. 2012. "Prinsip-prinsip Pemasaran". Edisi 13 Jilid 1 : Jakarta.

Sugiyono. 2011. “Metode Penelitian Kuantitatif, Kualitatif dan R\&D”.Bandung : Alfabeta.

Kotler, Philip dan Kevin Kane Keller. 2008. "Manajemen Pemasaran". Jakarta : PT Indeks.

Kotler, Philip dan G. Amstrong. 2007. "Prinsip-PrinsipPemasaran”.Jakarta : Erlangga.

Irawan, Handi. 2009. “10 Prinsip Kepuasan Pelanggan”. Jakarta : Elex Media Computindo.

Suryono, Capt. R.P. 2007.”SHIPPING :Pengangkutan Intermodal Ekspor Impor Melalui Laut (Edisi 4)”. Jakarta : PPM.

\section{Jurnal :}

Ghufrony, Ahmad. 2016. "Pengaruh Kualitas Pelayanan dan Harga Terhadap Kepuasan dan Loyalitas Pelanggan Pada Toko Retail Bahan-Bahan Bangunan Di Kecamatan Dungkek". Jurnal "PERFORMANCE" Bisnis dan Akuntansi Vol.VI. Universitas Wiraraja Sumenep. Madura.

Eri Pratiwi, Annisa. 2017. "Pengaruh Kualitas Pelayanan dan Kepercayaan Terhadap Loyalitas Pelanggan Dengan Kepuasan Pelanggan Sebagai Variabel Intervening (Studi Kasus Pada DNI SKIN CENTER Cabang Bintaro)".

Caroline, Olive dan Candra Kuswoyo. 2013. "Pengaruh Kualitas Pelayanan dan Harga Terhadap Loyalitas Pelanggan Melalui Kepuasan Pelanggan Hotel Zodiak Di Kota Bandung".

Wibawa, Padma T, Naili Farida dan Sari Listyorini. 2014. "Pengaruh Kualitas Pelayanan, Harga dan Promosi Terhadap Loyalitas Pelanggan Melalui Kepuasan Pelanggan PT. Matahari Silverindo Jaya Semarang".

Wijayanti, Retno Ika. 2012. "Peranan Freight Forwarder Dalam Pelaksanaan Ekspor pada PT. Purindo Logistics di Sukoharjo. 